\title{
アルミニウム合金の塑性変形に伴ら すべり帯長さの結晶粒径依存性
}

\author{
上谷 保裕* ·松田 健二** \\ 多々 静夫**. 池野進*** \\ Grain size dependence of slip band length with \\ plastic deformation in aluminum alloy
}

Yasuhiro UETANI*, Kenji MATSUDA**
Shizuo TADA** and Susumu IKENO***

Slip bands formed after small additional deformation $(\Delta \varepsilon=0.5 \%)$, are observed as straight lines in the lower strain region and at that strain region the stress-strain curve can be approximated by the Ludwik equation. The measurements of slip band length have been made in this strain region for various grain sizes of aluminum and $\mathrm{Al}-5 \%$ $\mathrm{Mg}$ alloy. The slip band length decreases with strain. At constant strain, the larger the grain size is, the longer is the slip band length in both aluminum and $\mathrm{Al}-5 \% \mathrm{Mg}$ alloy specimens. The linear relation between flow stress and inverse square root of grain size is not observed at higher strain region. On the other hand, linear relation between flow stress and inverse square root of slip band length can be seen at any strains. At constant grain size, linear relations are also observed with decreasing strain between flow stress and inverse square root of slip band length, and the slopes of those linear lines are almost the same, irrespectively of the grain size. Slip band length-strain curves calculated from the Ludwik equation are in good agreement with the experimental stress-strain curves.

Keywords: plastic deformation, slip band length, Hall-Petch relation, Ludwik equation, stress-strain curves, aluminum alloys

(Received December 8, 1989)

\section{1. 緒言}

前報1 において，アルミニウム合金の応力ーひずみ曲 線をLudwik の近似式 ${ }^{2)}$ で処理すると, 塑性変形の初期 と後期でそれぞれ 2 本の曲線を用いると近似できること を報告した。そのときに初期の曲線で近似できるひずみ 範囲が, 用いた試料の塑性変形による加工硬化挙動の本 性を表しており，後期のひずみ領域は塑性变形中に同時 に起こる動的回復の影響を大きく受けていると推察し た。

一般に, 単結晶試料では変形中に試料表面に表れるす
ベり線の挙動が塑性変形挙動と密接に関係し3), 応力 ひずみ曲線の解釈がすべり線の挙動を基礎としてなされ ている4)。また，黄銅の多結晶試料においては，すべり 帯の長さが転位の平均自由行程を間接的に示していると いら推察から变形応力との対応を調べたり, すべり帯と ひずみ量との関係を調べたりされている5)。しかし，ア ルミニウムおよびその合金においては微小ひずみ領域か ら詳細にすべり帯の挙動を調べた報告はなく, 変形応力 とすべり帯の関係はいまだに明確とはいい難い。 そこで, 本研究では動的回復が生じないと思われるよ らな初期ひずみ領域において, 変形中に現れる試料表面

* 富山県立技術短期大学 (富山県)。Toyama Prefectural College of Technology (Imizu-gun, Toyama).

** 富山大学工学部 (富山市)。Faculty of Engineering, Toyama University (Toyama-shi, Toyama).

*** 富山大学地域共同研究センター (富山市)。Center for Cooperative Research, Toyama University (Toyamashi, Toyama). 
Table 1 Analysis of the specimens used (wt \%)

\begin{tabular}{l|c|c|c|c|c|c|c|c|c}
\hline \hline \multirow{2}{*}{ specimen } & \multicolumn{8}{|c}{ element (wt\%) } \\
\cline { 2 - 9 } & $\mathrm{Si}$ & $\mathrm{Fe}$ & $\mathrm{Cu}$ & $\mathrm{Ti}$ & $\mathrm{Mn}$ & $\mathrm{Cr}$ & $\mathrm{Zn}$ & $\mathrm{Mg}$ & $\mathrm{Al}$ \\
\hline $\mathrm{Al}$ & 0.01 & 0.01 & - & - & 0.01 & - & - & - & $\mathrm{bal}$. \\
$\mathrm{Al}-5 \% \mathrm{Mg}$ & - & - & - & - & 0.02 & 0.01 & - & 5.05 & $\mathrm{bal}$. \\
\hline
\end{tabular}

のすべり帯を詳細に調べ，応力とすべり帯長さとの関係 を明らかにしよらと試みた。また，すべり帯長さと応力 一ひずみ曲線の関係を検討した結果について報告する。

\section{2. 実験方法}

試料はTable 1 に組成を示したよらな純アルミニウム および $\mathrm{Al}-5 \% \mathrm{Mg}$ 合金（本文中では $5 \% \mathrm{Mg}$ 合金と呼ぶ） の 2 種類である。純アルミニウム試料は冷間鍛造, 圧 延, 熱処理を組み合わせて 60 か $640 \mu \mathrm{m}$ の結晶粒径に 調整し， $5 \% \mathrm{Mg}$ 合金は熱間および冷間圧延と熱処理を 組み合わせて 60 から $400 \mu \mathrm{m}$ の結晶粒径に調整した。引 張試験片は平行部長さ $18 \mathrm{~mm}$, 幅 $6 \mathrm{~mm}$, 厚さ $0.9 \mathrm{~mm}$ の板状試験片とし, 最終熱処理前に機械的研磨を行って 寸法調整を行い，熱処理後は電解研磨をわずかにかけて 試料表面を鏡面状態に仕上げた。引張試験の手順は，ま ずチャート上で $0.5 \%$ のひずみを付加し, 試験機から試 験片を取り外して, 表面模様を Nomarski 型微分干渉顕 微鏡で観察, 撮影した。その後, 再び所定のひずみ量ま で引張変形し, 試験片を取り外して, 表面を電解研磨で 鏡面として再度 $0.5 \%$ の付加ひずみを与えて表面の観察 を行った。このよらな手順を繰り返し， Ludwik 近似が でさる初期ひずみ段階で, 同時にすべり帯が直線的で長 さ測定が可能なひずみ領域で, 試験片表面のすべり帯を 観察した。すべり帯長さは最低30個の結晶粒を対象にし て測定した。比較のために相対すべり帯長さを次の手順 で測定した。結晶粒内で実際に観察されるすべり帯の長 さと, そのすべり帯を延長し結晶粒界に接するまでの長 さの両方を測定し，両方の和でそのすべり帯が最大にな りらる長さとした。次に個々の最大になると思われるす ベり帯の長さで, 実際に観察されるすべり帯の長さを割 ったものを相対すべり帯長さとした。

引張変形は島津製オートグラフ DSS5000型を用い, 純アルミニウムは室温で引張変形し， $5 \% \mathrm{Mg}$ 合金は液 体ちっ素中で行った。液体ちっ素中で引張試験した理由 は， $5 \% \mathrm{Mg}$ 合金を室温で変形するとセレーションが発 生して均一変形しなくなるために評価が困難となるため である。また, 引張条件として初期ひずみ速度 $4.63 \times$ $10^{-4} / \mathrm{s}$ を用いた。なお, 本文では真応力を応力, 真ひ ずみをひずみとしている。

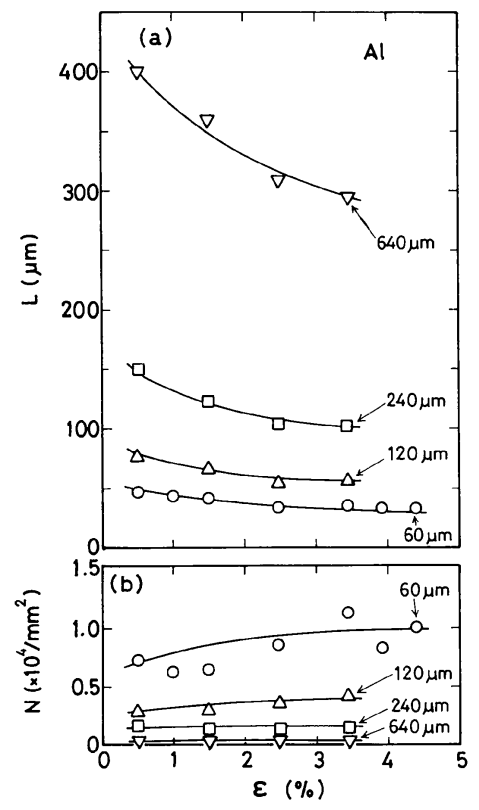

Fig. 1 Slip band length $(L)$ and number of slip bands per unit area $(N)$ as a function of strain for various grain sizes of aluminum at room temperature.

\section{3. 実験結果および考察}

\section{1 すべり帯長さとひずみ量の関係}

Fig. 1(a)は, 60 から $640 \mu \mathrm{m}$ の各結晶粒径を持つ, 純 アルミニウム試料の引張時における表面を観察し，すべ り帯長さを測定した結果である。ここで, 各測定点の值 は結晶粒30個の平均值を取ったものである。また，すで に述べたごとく，ひずみ初期で Ludwik 近似ができる限 界以上にひずみ量が大きくなると, すべり帯の形状が直 線的でなくなるために正確な長さが測定できなくなる。 純アルミニウムの場合はこの限界のひずみ量の值が小さ く, 最大の值を持つ $60 \mu \mathrm{m}$ の試料でも測定できる最大の ひずみ量は泳ぼ4.5\%程度であっだ。

同一ひずみ量で比較すると，結晶粒径が大きいものほ どすべり帯長さが長く，またいずれの結晶粒径の試料に おいても, すべり帯長さが変形量が増すと共に減少して いることがわかる。Fig. 1(b) は，そのときの単位面積 当たりのすべり帯の数を示しているが，結晶粒径が小さ

* 純アルミニウムの応力ーひずみ曲線の初期ひずみ領 域において，Ludwik式で近似できる最大（限界） のひずみ量は，いずれの結晶粒径の試料において も，すべり帯長さが測定できる限界のひずみ量より 約 $1 \%$ 程度大きかった。 $5 \% \mathrm{Mg}$ 合金では，すべり 帯長さが測定できる最大のひずみ量に比べ, Ludwik 近似できるひずみ量はほぼ 8 から10\%大きかっ た。 

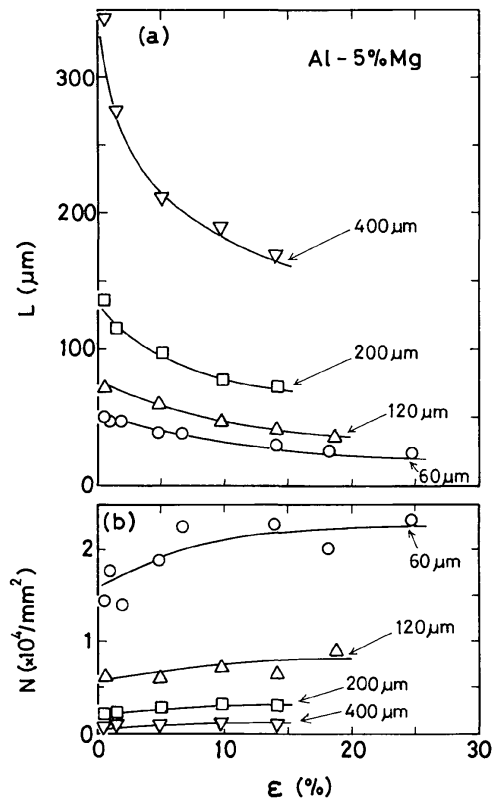

Fig. 2 Slip band length $(L)$ and number of slip bands per unit area $(N)$ as a function of strain for various grain sizes of $\mathrm{Al}-5 \% \mathrm{Mg}$ alloy at $77 \mathrm{~K}$.

いほどすべり帯の数が多いことがわかる。すべり帯の数 は結晶粒径 240 掞よび $640 \mu \mathrm{m}$ の試料ではひずみ量が大き くなっても匡とんど一定である。120 $\mu \mathrm{m}$ より小さい結 晶粒径の試料でひずみ量が増すと共に，すべり帯の数が わずかに上昇している。Fig. 2(a)は，60から400 $\mu \mathrm{m}$ の 結晶粒径を持つ $5 \% \mathrm{Mg}$ 合金を液体ちっ素中で引張変形 したときのすべり帯の平均長さを調べた結果であるが， いずれの結晶粒径の試料においても純アルミニウムと同 様に変形量が増すとすべり帯長さが減少していることが わかる。マグネシウムが含まれた結果, 純アルミニウム に比べひずみ初期の Ludwik 近似できるひずみ域が長く なり1)，同時にすべり帯長さが直線的で正確に測定でき るひずみ量も増加し, 結晶粒径 $60 \mu \mathrm{m}$ の試料では測定ひ ずみ量がほぼ25\%，最も小さい $400 \mu \mathrm{m}$ の試料でも約 14\%と非常に大きいことがわかる。また，Fig. 2(b)の 単位面積当たりのすべり帯の数の変化も汇とんど純アル ミニウムと同様に結晶粒径の小さい試料注どすべり帯の 数が多く，ひずみ量の増加と共にわずかに数が増加して いるよらに思われる。

\section{2 すべり帯長さと変形応力の関係}

一般に, 降状応力が Hall-Petchの関係により結晶粒 径に大きく依存している6)ことはよく知られている。

Fig. 3 は, 純アルミニウムに打いて結晶粒径を60から $640 \mu \mathrm{m}$ に変化させたときの変形応力の結晶粒径依存性 をHall-Petchの関係式により検討した結果である。図

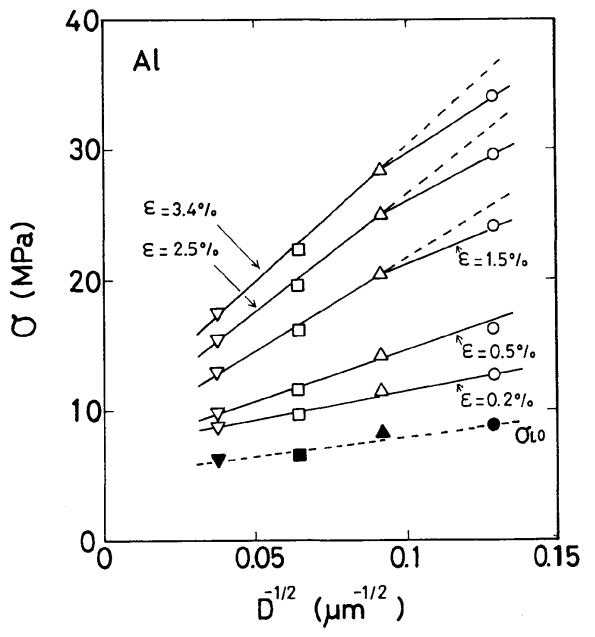

Fig. 3 Relation between flow stress at various strains and inverse square root of grain size $\left(D^{-1 / 2}\right)$ for aluminum at room temperature. In this figure, $\sigma_{L 0}$ obtained by use of the Ludwik equation $\sigma=\sigma_{L 0}+A$ $\varepsilon^{n}$ for stress-strain curves at lower strains are also plotted.

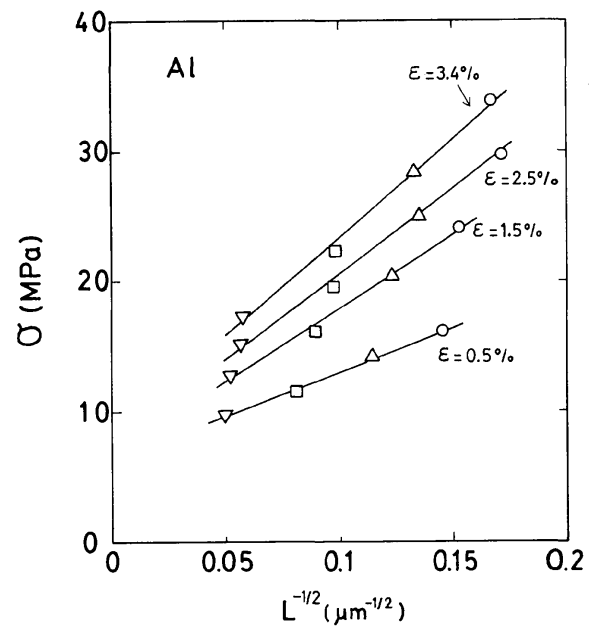

Fig. 4 Relation between flow stress at various strains and inverse square root of slip band length $\left(L^{-1 / 2}\right)$ for aluminum at room temperature.

からわかるよらに，Ludwik 近似に使用した塑性変形開 始応力 $\sigma_{L 0}$ および $0.2 \%$ 耐力は結晶粒径の平方根の逆数 と直線関係が成り立っている。一方, Hall-Petchの関係 を降状応力から拡張し, 塑性変形領域でも変形応力と結 晶粒径の平方根の逆数との間に直線関係が成り立つとい ら報告がある7)。図からわかるよらに，本結果でもひず み量が $0.5 \%$ 以下と小さい間は両者の間に直線関係が成 り立っている。しかし，ひずみ量がそれ以上になると一 本の直線では表せなくなっている。ひずみ量が大きくな ると，拡張した Hall-Petchの関係が適用できなくなる 


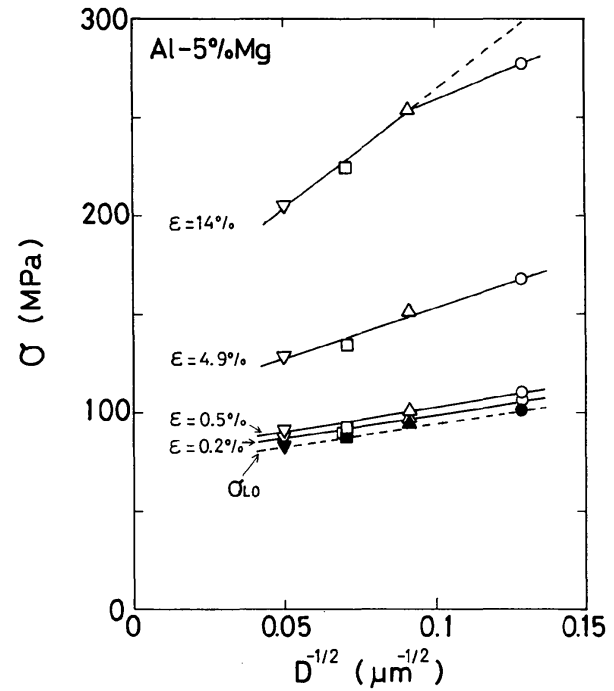

Fig. 5 Relation between flow stress at various strains and inverse square root of grain size $\left(D^{-1 / 2}\right)$ for $\mathrm{A}^{-}$ $5 \% \mathrm{Mg}$ alloy at $77 \mathrm{~K}$. In this figure, $\sigma_{L 0}$ obtained by use of the Ludwik equation are also plotted.

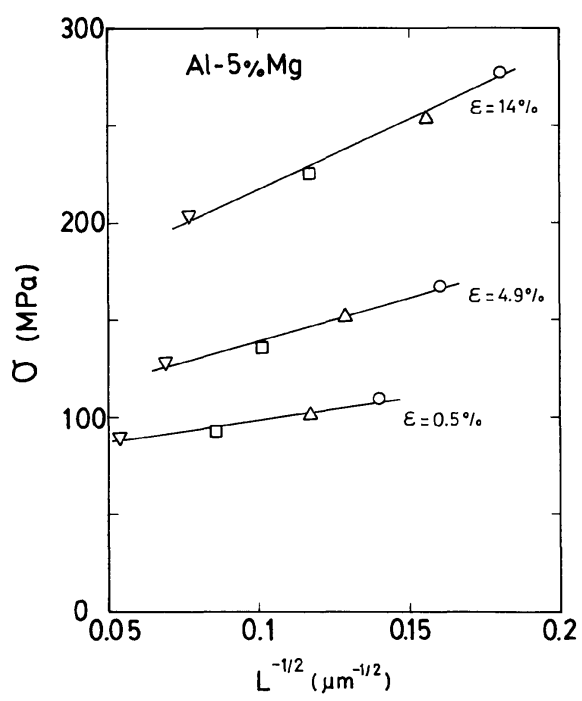

Fig. 6 Relation between flow stress at various strains and inverse square root of slip band length $\left(L^{-1 / 2}\right)$ for $\mathrm{Al}-5 \% \mathrm{Mg}$ alloy at $77 \mathrm{~K}$.

現象も知られている8 ${ }^{8)}$ 。Fujita と Tabata ${ }^{9)}$ は純アルミ= ウムにおいて, 変形開始直後では結晶粒径が変形応力を 支配するが，七ルが形成される前段階の低ひずみ側で は, 転位のもつれによる平均自由行程の減少が変形応力 を支配し，高ひずみ側では変形応力がセル径に依存する ために Hall-Petch の関係式が成り立たなくなると推論 している。本実験においては，透過電子頙微鏡観察によ ると，すべり帯が直線的に観察されるひずみ領域はいず

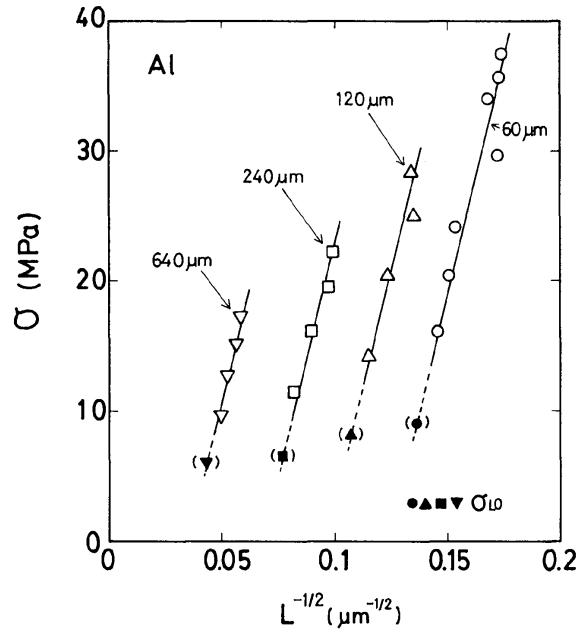

Fig. 7 Relation between flow stress at various grain sizes and inverse square root of slip band length $\left(L^{-1 / 2}\right)$ for aluminum at room temperature.

れの結晶粒径の試料においても，ひずみ量が小さく，転 位はをだ明瞭なセルを形成していなかった。したがっ て，塑性変形の増加と共に導入される転位によるもつれ が転位の平均自由行程を減少させ, 変形応力を上昇させ る段階であると考えられる。Miyazaki と Fujita ${ }^{10)}$ は結晶 粒径の異なる純銅を用いて検討し，アルミニウム同様に 変形量が大きいところでは変形応力と結晶粒径の平方根 の逆数とが一本の直線で表せないことを見いだし，報告 している。彼らは純銅の場合は, 試料表面におけるすへ り帯長さを転位の平均自由行程に対応するものとして整 理し直し，変形応力とよい関係が得られたことを報告し ている。そこで，純アルミニウムの場合もすべり帯長さ が，転位の平均自由行程に対応しているのではないかと 考え，次式6)検討した。

$$
\sigma=\sigma_{0}+k L^{-1 / 2}
$$

ここで $\sigma$ は変形応力, $\sigma_{0}$ は可動転位に対する摩擦力, $k$ は定数，Lはすべり帯の長さである。（1）式に従って変 形応力とすべり帯長さの関係に取り直したのが，Fig. 4 である。図中にはFig. 3 で示した Ludwik 近似による塑 性変形の開始する応力 $\sigma_{L 0}{ }^{1}$ お。よび $0.2 \%$ 耐力との関係は すべり帯が観察し難かったことから載せていない。図か らわかるように, Fig. 3 の結晶粒径への依存性の場合に みられた $1.5 \%$ 以上の高ひずみ側での折れ曲がり現象は みられず，どのひずみ量に対しても直線関係が認めら れ，(1)式が本実験範囲ではよく合らことがわかる。5\% $\mathrm{Mg}$ 合金で同様の検討を行ったのが，Fig. 5 および Fig. 6 である。Fig. 5 の結晶粒径と変形応力との関係か らわかるよらに，一本の直線で表せられなくなるひずみ 量は，この場合はかなり大きく $14 \%$ ひずみ程度となって 
Vol. 40 , No. 7

いる。この場合も，Fig. 6 にみるごとく，すべり帯の平 方根の逆数と变形応力にはいずれのひずみ量においても 直線関係がみられるようである。したがって，本実験で 測定したすべり帯長さは転位の平均自由行程と何らかの 関係を持っており, 本実験条件下では変形応力がすべり 帯長さで評価できるものと考兄られる。

\section{3 すべり帯長さと応力ーひずみ曲線の関係}

Fig. 7 は, Fig. 4 の純アルミニウムにおける变形応力 とすべり帯長さの結果を各結晶粒径の試料ごとに整理し 直したものである。図からわかるように，各結晶粒径の 試料でいずれも変形応力と結晶粒径の平方根の逆数 $L^{-1 / 2}$ の間に直線関係が認められる。したがって， $L^{-1 / 2}$ とひずみ $\varepsilon$ をいると応力ーひずみ曲線を表現できるの ではないかと考えた。応力ーひずみ曲線を表す Ludwik 近似式 ${ }^{2)}$

$$
\sigma-\sigma_{L 0}=A \varepsilon^{n}
$$

( $A$ は定数, $n$ 沖加工硬化指数) であり, Fig. 7 から結晶 粒径一定の場合の変形応力とすべり帯長さの関係が次式 (3)となる。

$$
\sigma-\sigma_{L 0}=B\left(L^{-1 / 2}-L_{0}^{-1 / 2}\right)
$$

ここで，Bは係数， $L_{0}$ は応力が $\sigma_{L 0}$ のときの予想される すべり帯長さである。Fig. 7 亿おいて各結晶粒径の試料 での直線の延長上に $L_{0}$ があると仮定し，Fig. 3 亿おけ る $\sigma_{L 0}$ の值を用いて外挿した值 (Table 2 参照) を黒印 で図中に併記している。Fig. 7 亿打いて，各結晶粒径の 試料で得られた直線はいずれもほぼ平行であり，傾きが 一致しているように思われる。そこで各結晶粒径の試料 における黒印の位置を原点とする（すなわち綐軸に $\sigma 一$ $\sigma_{L 0}$, 横軸に $L^{-1 / 2}-L_{0}^{-1 / 2}$ を取る) ように取り直したの がFig. 8(a)である。図からわかるように, 結晶粒径の 異なる試料の值はいずれも一本の直線上にのるように思 われる。

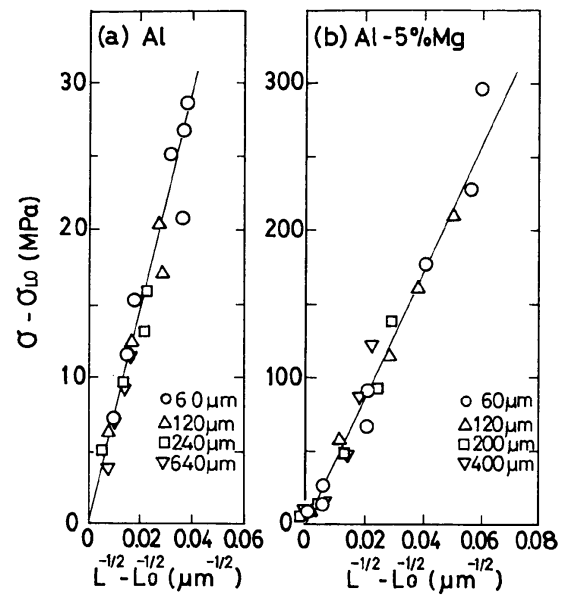

Fig. 8 Relation between $\sigma-\sigma_{L 0}$ and $L^{-1 / 2}-L_{0}^{-1 / 2}$ for (a) aluminum at room temperature and (b) $\mathrm{Al}-5 \%$ $\mathrm{Mg}$ alloy at $77 \mathrm{~K}$.

いま，(2)および(3)式から

$$
L^{-1 / 2}-L_{0}^{-1 / 2}=(A / B) \varepsilon^{n}
$$

の関係が成り立つと思われる。(4) 式は左辺を緃軸, $\varepsilon$ を横軸にとったとき，原点を通り，指数 $n$ で描かれる曲 線が $\varepsilon=1 て ゙ ~(A / B)$ の值となることを示している。 $A$ およびnは Ludwik 近似から得られる定数であり, 結晶 粒径が異なれば異なる値を持つ（Table 2 参照）が， $B$ はFig. 8(a)にみられるように，結晶粒径によらず一定 の值を持つものである。この場合は $B=750(\mathrm{MPa} /$ $\left.\mu \mathrm{m}^{-1 / 2}\right)$ である。Fig. 9 はその結果であり，各結晶粒径 の試料でのすべり帯長さとひずみ量との関係をみたもの であるが，ひずみ量が大きくなると共に $\left(L^{-1 / 2}-L_{0}^{-1 / 2}\right)$ の值が曲線を描いて大きくなることがわかる。また，結 晶粒径が小さくなる汪ど曲線は上方に描かれている。図 の右の縦軸に実際の变形応力から Ludwik 近似による塑

Table $2 \sigma_{L 0}, A, n$ obtained by use of the Ludwik equation ${ }^{2)} \sigma=\sigma_{L 0}+A \varepsilon^{n}$ for the stress-strain curves at lower strains, and $B, L_{0}^{-1 / 2}$ obtained by use of the equation $\sigma=\sigma_{L 0}+B\left(L^{-1 / 2}-L_{0}^{-1 / 2}\right)$ approximating the relation between stress and slip band length

\begin{tabular}{l|c|c|c|c|c|c}
\hline \hline \multicolumn{2}{c|}{ specimen } & \multicolumn{3}{|c|}{$\sigma=\sigma_{L 0}+A \varepsilon^{n}$} & \multicolumn{2}{c}{$\sigma=\sigma_{L 0}+B\left(L^{-1 / 2}-L_{0}^{-1 / 2}\right)$} \\
\hline & G.S. $(\mu \mathrm{m})$ & $\sigma_{L 0}(\mathrm{MPa})$ & $A(\mathrm{MPa})$ & $n$ & $B\left(\mathrm{MPa} / \mu \mathrm{m}^{-1 / 2}\right)$ & $L_{0}^{-1 / 2}\left(\mu \mathrm{m}^{-1 / 2}\right)$ \\
\hline \multirow{4}{*}{$\mathrm{Al} * 1$} & 60 & 8.8 & 227 & 0.646 & 750 & 0.1357 \\
& 120 & 8.1 & 178 & 0.638 & 750 & 0.1073 \\
& 240 & 6.4 & 105 & 0.566 & 750 & 0.0764 \\
& 640 & 6.1 & 91 & 0.620 & 750 & 0.0427 \\
\hline \multirow{4}{*}{$\mathrm{Al-5 \%} \mathrm{Mg}^{* 2}$} & 60 & 101 & 1095 & 0.920 & 4500 & 0.1374 \\
& 120 & 93 & 1045 & 0.961 & 4500 & 0.1151 \\
& 200 & 87.2 & 975 & 1.025 & 4500 & 0.0860 \\
& 400 & 86 & 962 & 1.050 & 4500 & 0.0530 \\
\hline
\end{tabular}

${ }^{* 1}$ deformed at room temperature, ${ }^{* 2}$ deformed at $77 \mathrm{~K}$ 


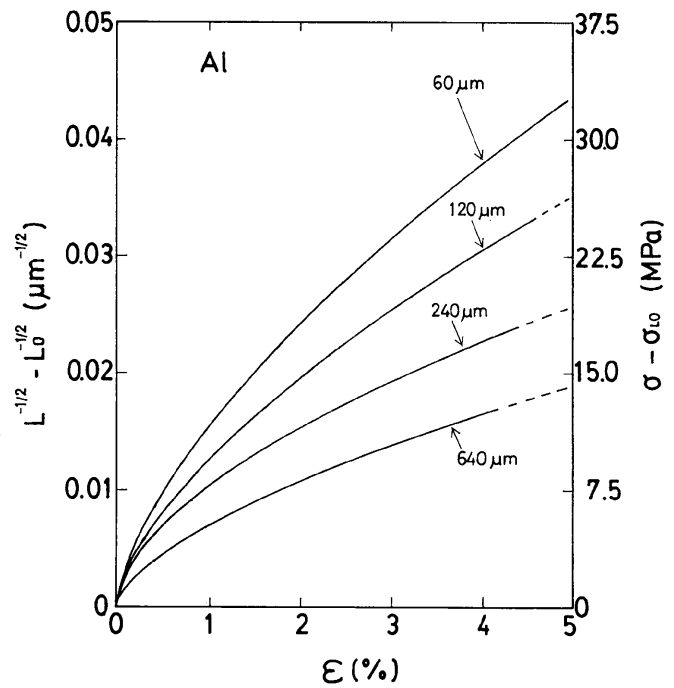

Fig. $9\left(L^{-1 / 2}-L_{0}^{-1 / 2}\right)$-strain curves for various grain sizes of aluminum at room temperature. In this figure, $\left(\boldsymbol{\sigma}-\boldsymbol{\sigma}_{L 0}\right)$-strain curves are also plotted. The two kinds of curves lie in the same locations.

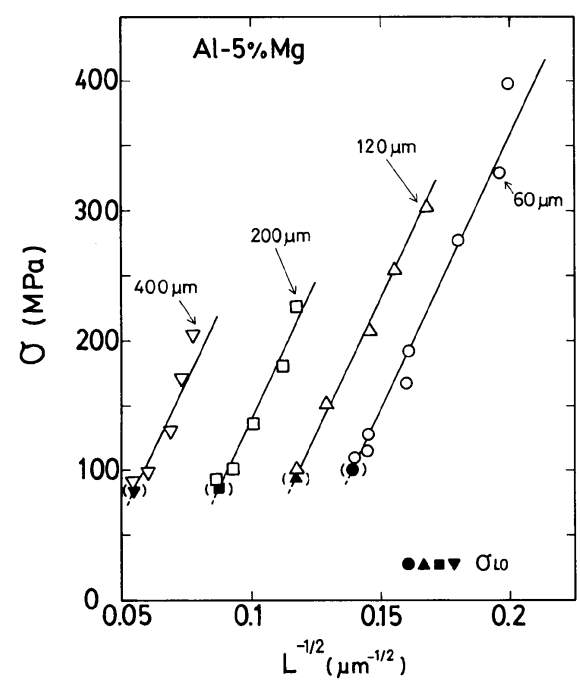

Fig. 10 Relation between flow stress at various grain sizes and inverse square root of slip band length $\left(L^{-1 / 2}\right)$ for $\mathrm{Al}-5 \% \mathrm{Mg}$ alloy at $77 \mathrm{~K}$.

性变形の開始応力を差し引いた值を取って, 実際の応力 一ひずみ曲線を描いた結果，すべり帯一ひずみ曲線と応力 ーひずみ曲線が非常によく一致し，図中で区別すること ができず，いずれも一本の曲線で両者が示されている。

Fig. 10は, Fig. 6 の $5 \% \mathrm{Mg}$ 合金の結果を，各結晶粒 径の試料ごとに整理し直した結果である。四からわかる ように，各結晶粒径の試料でいずれも純アルミニウムと 同様に変形応力と結晶粒径の平方根の逆数の間に直線関 係が認められる。図中に黒印で示した各点は，Fig. 5 に

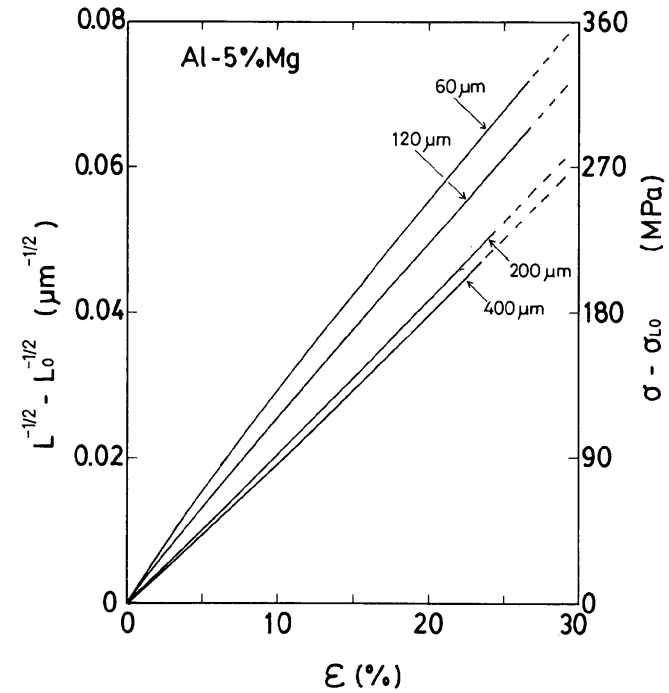

Fig. $11\left(L^{-1 / 2}-L_{0}^{-1 / 2}\right)$-strain curves for various grain sizes of $\mathrm{Al}-5 \% \mathrm{Mg}$ alloy at $77 \mathrm{~K}$. In this figure, $\left(\sigma-\sigma_{L 0}\right)$-strain curves are also plotted. The two kinds of curves lie in the same locations.

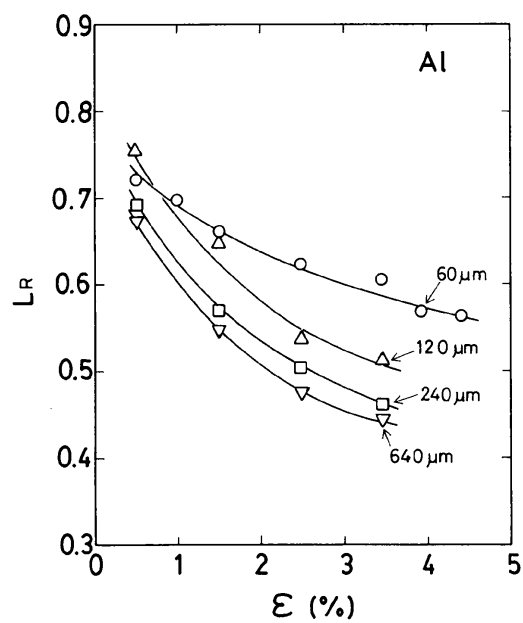

Fig. 12 Relative slip band length $\left(L_{R}\right)$ as a function of strain for various grain sizes of aluminum at room temperature.

拈ける $\sigma_{L 0}$ の值を用いて外捙した $L_{0}$ の值 (Table 2 参照) である。Fig. 10において，純アルミニウムと同様に各 結晶粒径の試料で得られた直線はいずれもほぼ平行であ るよらに思われる。そこで各結晶粒径の試料における黒 印の位置を原点とするように取り直したのが Fig. 8(b) である。図からわかるように，結晶粒径の異なる試料の 值はいずれも一本の直線上にのるように思われる。この 場合は傾きが $4500\left(\mathrm{MPa} / \mu \mathrm{m}^{-1 / 2}\right)$ である。いま, 純アル ミニウムと同様な検討を行らため Table 2 に示した各定 数の值を用いて(4)式に当てはめた結果がFig. 11であ 


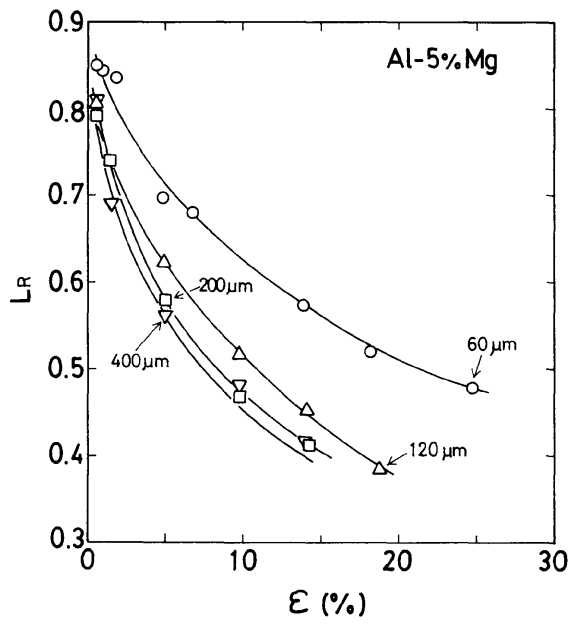

Fig. 13 Relative slip band length $\left(L_{R}\right)$ as a function of strain for various grain sizes of $\mathrm{Al}-5 \% \mathrm{Mg}$ alloy at $77 \mathrm{~K}$.

る。 $5 \% \mathrm{Mg}$ 合金の場合も，実際の応力ーひずみ曲線とす ベり帯一ひずみ曲線とが非常によく一致し, 図中で区別 することができず，いずれも一本の曲線で両者が示され た。

Dong と Thompson ${ }^{5)}$ は, 結晶粒径が30,65および300 $\mu \mathrm{m}$ の70-30黄銅を用いてすべり帯長さとひずみ量の関 係を調べ，ひずみ量が大きくなると共にすべり帯長さが いずれの結晶粒径の試料に掞いても短くなることを報告 している。彼らは一定ひずみ量でみると，すべり帯長さ が結晶粒径が大きくなるほど長くなり, それぞれの試料 でひずみ量が増加する割合に対するすべり帯の減少割合 が異なるが，実際のすべり帯長さを結晶粒径に対する相 対長さにとり直すと結晶粒径が異なってもほぼ一本の減 少曲線で表すことができるとしている。もしそらなら， すべり帯の相対長さで結晶粒径が異なる試料の変形応力 が直接評価できることになる。Fig. 12およびFig. 13は 本結果を彼らと同じすべり帯の相対長さに取り直した結 果である。純アルミニウムの Fig. $12,5 \% \mathrm{Mg}$ 合金の Fig. 13 と、いずれの図においても結晶粒径が異なれば, それぞれ異なる曲線にのって相対すべり帯長さが減少し ている。またひずみ量が増すほどそれぞれの結晶粒径の 試料での相対すべり帯長さの值が異なっている。Dong と Thompson ${ }^{5)}$ と本結果の違いは黄銅とアルミニウム合 金という試料の違いか，本実験での付加ひずみ量 $0.5 \%$ に対して彼らは $2.5 \%$ といら大きな付加ひずみを加えて いるために生じた結果とも考えられるが，彼らのデータ は本結果に比べばらつきが大きいように思われるので, 70-30黄銅に関する検討は今後の課題である。本結果で は，彼らと異なり，変形応力とすべり帯長さの平方根の 逆数が対応する。また合金が同じなら結晶粒径が異なる
ときでも， $L^{-1 / 2}$ が変化する割合に対して変形応力は常 に一定の変化量を示すといら結果が得られた。

\section{4. 結言}

純アルミニウムおよび $5 \% \mathrm{Mg}$ 合金を用いて引張試験 し, 変形中に生じる試料表面のすべり帯の観察を行い, 変形応力との関係を調べた。得られた結果を要約する と，以下のごとくである。

(1) いずれの試料においても，ひずみが増すと共にす ベり帯長さは短くなるが, 同一ひずみ量で比較すると結 晶粒径が大きい汪どすべり帯長さは長かった。

（2）ひずみ量が小さいときにみられる, 変形応力と結 晶粒径の平方根の逆数との間の直線関係は, ひずみ量が 大きくなると認め難くなる。一方, 変形応力とすべり帯 長さの平方根の逆数との関係ではいずれのひずみ量でも 直線関係が認められた。

（3）結晶粒径が一定のとき，変形応力とひずみ量によ って異なるすべり帯長さの平方根の逆数との間に直線関 係が認められた。しかも, この直線の傾きは結晶粒径が 異なる試料においてもほとんど变化しなかった。

（4）すべり帯と変形応力の関係に Ludwik 近似式の係 数 $\mathrm{A}$ および指数 $\mathrm{n}$ の值を用いることにより，すべり帯 長さーひずみ曲線が描かれ, 実際の応力ーひずみ曲線と非 常によく一致した。

本実験の遂行に当たり，試料の分析をして戴いた新日 軽(㑣)高岡製造所技術課の皆様に感謝致します。また，実 験に協力した元富山大学学生の広瀬博章君に感謝しま के

\section{参考 文 献}

1）上谷保裕, 浅井吉夫, 池野 進, 多々静夫 : 軽金 属, 36 (1986), 279.

2) P. Ludwik: Elemente der Technologischen Mechanik, Springer-Verlag, Berlin, (1909)

3）丸川健三郎：転位論一その金属学への応用一，日 本金属学会編，丸善，(1971）, 77.

4）長谷川正, 辛島誠一：日本金属学会会報, 9 (1970), 29.

5) H. Dong and A. W. Thompson: Metall. Trans. A, 16A (1985), 1025.

6） W. J. M. Tegart：金属の力学的性質（高村仁一, 三浦 精，岸 洋子共訳)，丸善，(1975)，182.

7) R. Armstrong, I. Codd, R. M. Douthwaite and N. J. Petch: Phil. Mag., 7 (1962), 45.

8) T. Tabata, K. Takagi and H. Fujita: Trans. JIM, 16 (1975), 569.

9) H. Fujita and T. Tabata: Acta Metall., 21 (1973), 355.

10) S. Miyazaki and H. Fujita: Trans. JIM, 19 (1978), 438. 